Annals of Glaciology $3 \quad 1982$

(C) International Glaciological Society

\title{
THE BRINE ZONE IN THE MCMURDO ICE SHELF,
}

\section{ANTARCTICA}

by

\author{
A. Kovacs, A. J. Gow and J. Cragin
}

(U.S. Army Cold Regions Research and Engineering Laboratory, Hanover, New Hampshire 03755, U.S.A.)

\section{ABSTRACT}

Infiltration of brine into the McMurdo Ice Shelf is dominated by wave-like intrusions of sea-water triggered by periodic break-outs of the ice front. Observations of a brine step $4.4 \mathrm{~m}$ in height in the McMurdo Ice Shelf show that it has migrated about $1.2 \mathrm{kIn}$ in four years. The present brine wave is overriding an older brine-soaked layer. This migration is proof of the dynamic nature of the step, which is the leading edge of a brine wave that originated at the ice front after a major break-out of the McMurdo Ice Shelf. The inland boundary of brine penetration is characterized by a series of descending steps that are believed to represent terminal positions of separate intrusions of brine of similar origin. The inland boundary of brine percolation is probably controlled largely by the depth at which brine encounters the firn/ice transition $(43 \mathrm{~m})$. However, this boundary is not fixed by permeability considerations alone, since measurable movenent of brine is still occurring at the inland boundary. Freeze-fractionation of the sea-water as it migrates through the ice shelf precipitates virtually all sodium sulfate, and preferentially concomitant removal of water by freezing in the pore spaces of the infiltrated firn produces residual brines approximately seven times more concentrated than the original sea-water.

\section{INTRODUCTION}

In Antarctica, brine-soaked firn has been observed in the Lazarev I ce Shelf (Dubrovin 1962), in a small ice shelf near Wilkes station (Stuart and Bull 1963), in the Wordie, Brunt, and Larsen ice shelves (Smith and Evans 1972), and in the Brunt Ice Shelf (Thomas 1973). However, the phenomenon is best known in the McMurdo Ice Shelf, as reported, for example, by Stuart and Bul1 (1963), Risk and Hochstein (1967), Heine (1968), Clough (1973), and Kovacs and Gow $(1975,1977)$. Several mechanisms have been suggested for brine soaking, e.g. vertical percolation of seawater from the bottom, lateral infiltration from the ice front, and upward diffusion along ice-crystal boundaries. This paper presents new findings on brine migration in the McMurdo Ice Shelf.

\section{RESULTS AND DISCUSSION}

The depth characteristics, lateral continuity, and inland boundary of sea-water infiltration into the McMurdo Ice Shelf were determined in January 1977 with a dual-antenna radio echo profile system. The methodology for use of the dual-antenna sounding system is described in Kovacs and Morey (1979).
The inland boundary of brine infiltration was profiled in detail in January 1977 , between Ross and White islands (Fig.1). Stations along the boundary were fixed by triangulation survey. The northern limit of this brine layer was originally delineated in 1967 (Clough and Bentley 1967, Clough 1973). In November 1973, new bamboo markers were placed at intervals along the boundary (J Clough personal communication). Resurvey of the existing markers, $2 S, 1 S$, $1 \mathrm{~N}, 2 \mathrm{~N}, 3 \mathrm{~N}$, and $4 \mathrm{~N}$ (Fig.1), on 18 January 1977 indicated that the brine layer had penetrated the ice shelf $197,129,73,55,10$, and $9 \mathrm{~m}$, respectively, or at an apparent rate of $0.168,0.110,0.062,0.047$, 0.008 , and $0.008 \mathrm{~m} \mathrm{~d}^{-1}$.

The brine-layer depth and the electromagnetic wave velocity velocities and dielectric constants determined from the radio echo profile data versus distance along the profile line shown in Figure 1 are listed in Table I. Also listed are surface elevations determined by topographic survey, and iceshelf depths determined by direct drill-hole measurement. These data allowed construction of a representative cross-section of the McMurdo Ice Shelf along our profile line (Fig.2). The location on 10 January 1977 of a large $(4.4 \mathrm{~m})$ step in the brine layer is shown, as is the inland termination of the brine infiltration, which is characterized by a series of descending steps. These features, as displayed on the graphic recorder, are shown in Figures 3 and 4 .

The position of the $4.4 \mathrm{~m}$-high step in the brine Tayer was reprofiled on 24 November 1978 and again on 20 January 1981. Between 10 January 1977 and 24 November 1978 this step or brine front had moved from about $2905 \mathrm{~m}$ to about $3610 \mathrm{~m}$ in from the ice front, an average advance rate of $1.037 \mathrm{~m} \mathrm{~d}^{-1}$.

As with the 4.4 m-high brine wave currently overriding an older brine-soaked firn horizon, the brine steps at the inland boundary represent past intrusions of brine triggered by periodic break-outs of the ice shelf. Through this process, firn at the ice front between sea-level and the top of the old brine horizon becomes exposed to the sea, and a new wave of sea-water begins to permeate the ice shelf. Froin the slope of the brine-soaked firn layer it was estimated that approximately $3 \mathrm{~km}$ of the ice shelf had to have broken off to allow for the $4.4 \mathrm{~m}$-high brine step. Paige (1971) reports that "the most extensive observed periods of ice-shelf break-out occurred in February of 1964 and 1965". Approximate?y $1500 \mathrm{~m}$ of ice shelf calved. Further calving occurred in 1966, 1967 and 1968, and apparently in 1970. No brine-wave record of these events was observed in the 
TABLE I. 1977 MCMURDO ICE SHELF STATION DATA ALONG TRAVERSE FROM ICE FRONT TO BEYOND ICE-SHELF MOVEMENT MARKER 307

\begin{tabular}{|c|c|c|c|c|c|c|c|}
\hline $\begin{array}{c}\text { Station } \\
\text { no. }\end{array}$ & $\begin{array}{c}\text { Distance } \\
\text { inland } \\
m\end{array}$ & $\begin{array}{c}\text { Freeboard } \\
\text { F } \\
m(+)\end{array}$ & $\begin{array}{c}\text { Brine } \\
\text { depth } \\
m(-)\end{array}$ & $\begin{array}{c}\text { Brine } \\
\text { elevation } \\
m(-)\end{array}$ & $\begin{array}{l}\text { Keel } \\
\text { depth } \\
\text { K } \\
m(-)\end{array}$ & $\begin{array}{l}\text { Real effec- } \\
\text { tive dielec- } \\
\text { tric constant } \\
\\
\quad \varepsilon_{\text {er }}\end{array}$ & $\begin{array}{c}\text { EM wave } \\
\text { velocity } \\
V \\
m n^{-1}\end{array}$ \\
\hline 1 & 40 & 3.9 & 4.7 & 0.8 & - & $1.81(x)$ & 0.223 \\
\hline 2 & 305 & 4.8 & - & - & $15.5\left(^{*}\right)$ & - & - \\
\hline 3 & 600 & 5.0 & 6.0 & 1.0 & - & 1.91 & 0.217 \\
\hline 4 & 750 & 5.6 & - & - & $20.0(*)$ & - & + \\
\hline 5 & 910 & 6.0 & - & - & $19.5(*)$ & - & - \\
\hline 6 & 1080 & 6.5 & 7.8 & 1.3 & $21.5(*)$ & 1.95 & 0.225 \\
\hline 7 & 1640 & 8.1 & 10.2 & 2.1 & - & 1.99 & 0.212 \\
\hline 8 & 2160 & 10.2 & 12.8 & 2.6 & - & 2.04 & 0.210 \\
\hline 9 & 2620 & 11.6 & 15.5 & 3.9 & - & 2.09 & 0.208 \\
\hline 10 & 2840 & 12.5 & 16.9 & 4.4 & - & 2.10 & 0.207 \\
\hline $10 b$ & 2900 & 12.7 & 21.5 & 8.8 & - & 2.18 & 0.203 \\
\hline 11 & 3280 & 14.4 & 23.6 & 9.2 & - & 2.18 & 0.203 \\
\hline 12 & 3940 & 15.6 & 25.4 & 9.8 & - & 2.22 & 0.201 \\
\hline 13 & 4550 & 16.7 & 26.7 & 10.0 & - & 2.25 & 0.200 \\
\hline 14 & 5190 & 17.6 & 27.9 & 10.3 & - & 2.29 & 0.198 \\
\hline 15 & 5640 & 18.2 & 29.2 & 11.0 & - & 2.32 & 0.197 \\
\hline 16 & 6160 & 19.4 & 31.2 & 11.8 & - & 2.33 & $0.196^{\circ}$ \\
\hline 17 & 6680 & 20.1 & 32.6 & 12.5 & - & 2.34 & 0.196 \\
\hline 18 & 7200 & 20.8 & 33.8 & 13.0 & - & 2.35 & 0.196 \\
\hline 19 & 7720 & 21.7 & 35.3 & 13.6 & - & 2.36 & 0.195 \\
\hline 20 & 8480 & 23.0 & 37.9 & 14.9 & - & 2.43 & 0.192 \\
\hline 21 high & 8800 & 23.4 & 40.6 & 17.2 & - & 2.46 & 0.191 \\
\hline 21 low & 8800 & 23.4 & 44.5 & 21.1 & - & 2.50 & 0.190 \\
\hline 22 high & 9080 & 23.8 & 45.5 & 21.7 & - & 2.49 & 0.190 \\
\hline 22 low & 9080 & 23.8 & 47.5 & 23.7 & - & 2.52 & 0.189 \\
\hline 23 & 9520 & 24.6 & - & - & $84.6(0)$ & - & - \\
\hline 24 & 9660 & 25.0 & 49.1 & 24.1 & $88.0(\varnothing)$ & 2.52 & 0.189 \\
\hline 307 & 9700 & 25.0 & - & - & - & - & - \\
\hline 25 & 9840 & 25.2 & - & - & $89.7(6)$ & - & - \\
\hline 26 & 10000 & 25.4 & - & - & $90.0(g)$ & - & - \\
\hline 27 & 10160 & 25.6 & - & - & $91.4(\varnothing)$ & - & - \\
\hline 28 & 10320 & 25.9 & - & - & $92.4(0)$ & - & - \\
\hline 29 & 10490 & 26.2 & - & - & $93.6(6)$ & - & - \\
\hline
\end{tabular}

(*) Drill-hole measurements.

(ø) Based on wavelet two-way travel time from snow surface to ice-shelf bottom minus two way travel time from ice surface to brine elevation at station 24 . The ice below brine termination elevation was assumed to have an $\varepsilon_{\text {er }}$ of 2.95 and therefore $a$ of $0.175 \mathrm{~m} \mathrm{~ns}^{-1}$.

(x) Between surface and brine layer.

radio echo profiles because it was apparently removed by subsequent break-outs. If the last ice-shelf breakout occurred in February 1970 and the brine wave was $2850 \mathrm{~m}$ in from the ice front in January 1977, then the average infiltration velocity of the brine wave would have been $1.21 \mathrm{~m} \mathrm{~d}^{-1}$.

Between 6 February and 22 March 1980, 1arge sections of the McMurdo Ice Shelf broke off ( $C$ Roper personal communication). During one period, the ice shelf was observed moving vertically 30 to $50 \mathrm{~mm}$ at an inland crack. A resurvey of the brine-profile line in January 1981 revealed that $1640 \mathrm{~m}$ of the ice shelf was missing. Based upon old records (Heine 1963, Paige 1971) this break-out is one of the largest recorded. A new brine-layer horizon about $1.4 \mathrm{~m}$ above above the old horizon at the ice front extended inland $375 \mathrm{~m}$ (Fig.2). This infiltration took $302 \mathrm{~d}$, an average rate of $1.24 \mathrm{~m} \mathrm{~d}^{-1}$.

Risk and Hochstein (1967) attributed the brinesoaked firn in the McMurdo Ice Shelf to lateral percolation from the ice front. They al so agree with Stuart and Bull (1963) that vertical brine infiltration occurs through low-density bottom firn. However, Risk and Hochstein limited the area where the latter mechanism occurs to a zone extending about $0.5 \mathrm{~km}$ in from the edge, where permeable firn was considered to be exposed due to bottom melting. If vertical infil- tration is occurring near the ice front, the top of the brine-soaked firn in this area should be near hydrostatic equilibrium with the sea-water. Our radio echo profile surveys showed that the brine layer, beginning at the very edge of the ice shelf, has a negative gradient. It therefore appears that permieable firn does not exist on the bottom of the ice shelf. The freezing of fresh water from the brine in the infiltrated firn has effectively blocked off interconnected pores, preventing upward migration of sea-water.

Thomas (1975) estimated a brine infiltration rate of $1.10 \mathrm{~m} \mathrm{~d}^{-1}$ for the Brunt I ce Shelf, where the firn density $\left(0.570 \mathrm{Mg} \mathrm{m} \mathrm{m}^{-3}\right)$, temperature $\left(-10^{\circ} \mathrm{C}\right)$ and pressure gradient ( 1 in 525) were more favorabie to sea-water infiltration. We can calculate a brine-flow velocity $(u)$ at station 10 following the procedure of Thomas, where

$$
u=\frac{B_{0}}{\eta} \frac{\partial p}{\partial x}
$$

and $B_{0}$ is the specific permeability of the firn, $n$ is the dynamic viscosity of the brine fluid and $a p / a x$ is the pressure gradient of the brine layer. Thomas has suggested that $B_{0}=9 \times 10^{-4} \mathrm{~d}^{2}$ where $d_{m}$ is the grain diameter, which we éstimate to be $2 \mathrm{~m}$ for 
$0.7 \mathrm{Mg} \mathrm{m}^{-3}$ firn. The firn temperature was $\sim-14^{\circ} \mathrm{C}$ and $\mathrm{n}$ for the brine at this temperature is $4.5 \times 10^{-3} \mathrm{~Pa}$ s. The hydraulic head, over a distance of $2580 \mathrm{~m}$ from station 1 to station 9 , is $3.1 \mathrm{~m}$. From Equation 1 we calculate a flow velocity of $9.68 \times 10^{-6} \mathrm{~m} \mathrm{~s}^{-1}$ or $0.84 \mathrm{~m} \mathrm{~d}^{-1}$. This value fits nicely between the average brine-wave velocity of $1.04 \mathrm{~m} \mathrm{~d}^{-1}$ which existed before the wave reached station 10 (10 January 1977 to 24 November 1978) and the average velocity of $0.67 \mathrm{~m} \mathrm{~d}^{-1}$ which occurred after the wave passed station 10 (24 November 1978 to 20 January 1981).

Core data obtained in November 1978 about $120 \mathrm{~m}$ inside and $60 \mathrm{~m}$ beyond the maximum inland position of the brine-layer intrusion, which occurred in January 1977, revealed that "impermeable" firn of density $0.82 \mathrm{Mg} \mathrm{m}^{-3}$ (ice by definition) was encountered at a depth of about $43 \mathrm{~m}$, or $7 \mathrm{~m}$ above the brine layer. The inland limit of brine-movement infiltration in permeable material of the McMurdo Ice Shelf is therefore controlled mainly by the depth at which brine encounters the firn/ice transition. At this boundary, firn containing liquid brine is presumably carried downward and densified by continued snow accumulation on the ice-shelf surface.

The slope of the brine layer was 1 in 832 from the ice front to station 9,1 in 910 from station 11 to station 20 , and 1 in 1500 from station 22 to 24 . The surface of the ice shelf beyond station 11 has a slope of 1 in 606, while the bottom is 1 in 137 .
If the brine layer along the profile line could maintain a slope of 1 in 830 beyond station 9 and could move instantly inland to intersect the "impermeable" firn/ice transition horizon, it would do so at a maximum about $14 \mathrm{~km}$ inland from the 1977 ice front. However, this cannot be expected to occur under existing infiltration conditions; as the brine moves inland, it will encounter denser and therefore less permeable firn as well as lower temperatures. These effects will slow the infiltration rate and probably limit inland penetration in the area of our profile to less than $11 \mathrm{~km}$.

A rate of bottom melting of the order of 0.9 to $1.2 \mathrm{~m}$ of ice $\mathrm{a}^{-1}$ has been estimated for stations 202 and 207 (see Fig.1) by Risk and Hochstein (1967). By assuming an ice bottom ablation rate of $0.9 \mathrm{~m} \mathrm{a}^{-1}$, it would take 69 a before the brine-infiltrated firn at station 24 became exposed to the sea. Similarly, if bottom melting was occurring at $1.2 \mathrm{~m} \mathrm{a}^{-1}$, it would take only 52 a before the brine-infiltrated firn reached the bottom of the ice shelf.

The typical ice-shelf movement rates shown in Figure 1 come from Heine (1967), except that of station 307 which came from the 1971-73 to 1978-79 summer-survey data on file at the New Zeal and Scott Base, Ross Island, Antarctica. In 1978-79, station 307 was moving at $84 \mathrm{~m} \mathrm{a}^{-1}$. The survey data also indicate that this station is slowing. It is assumed that the ice shelf in the area of station 307 will move westward at an average rate of $80 \mathrm{~m} \mathrm{a}^{-1}$ during

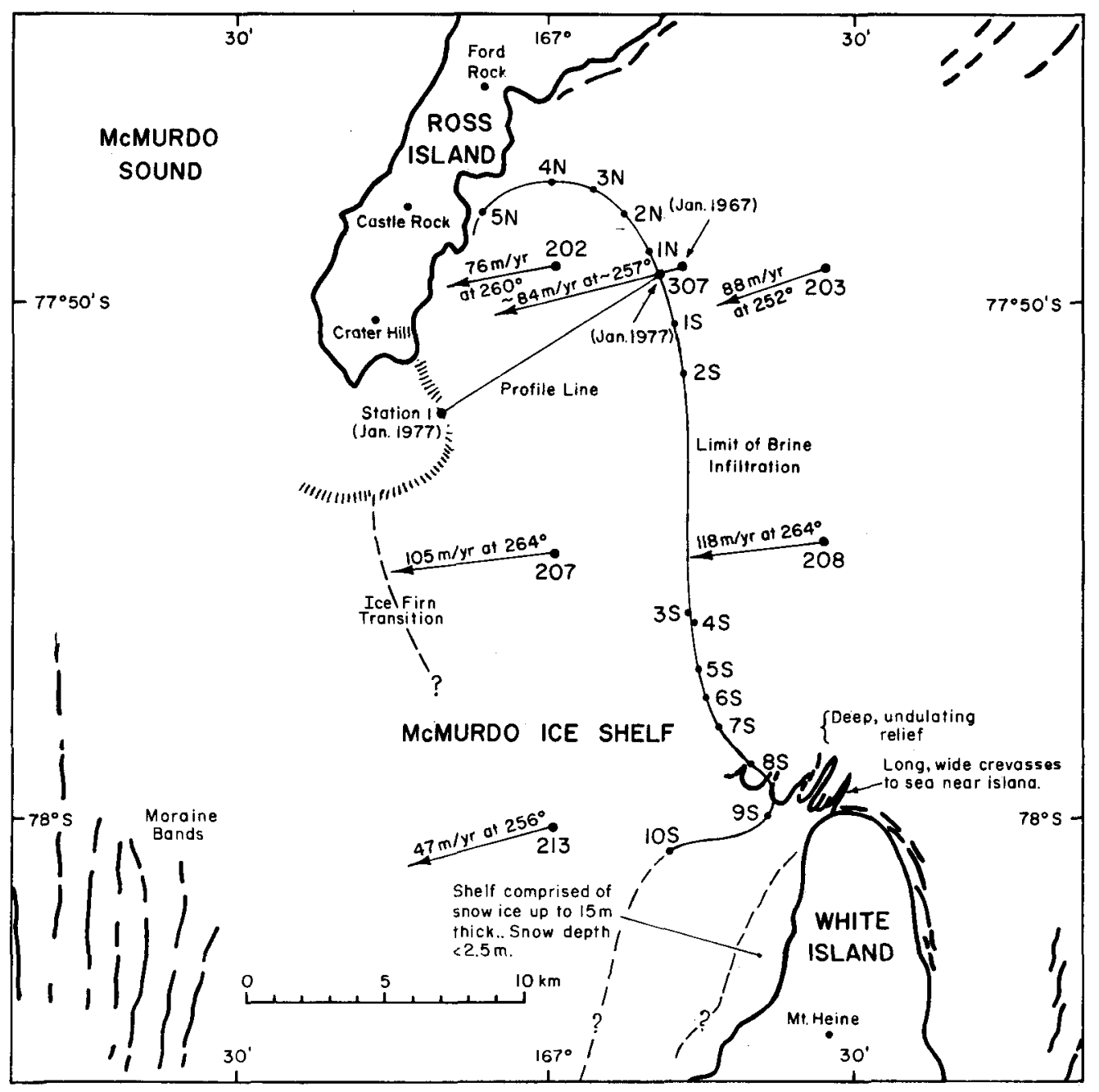

Fig.1. Map of the McMurdo Ice Shelf area. The ice/firn transition controls the western limit of brine infiltration. The ice-shelf surface west of this boundary is ice. 


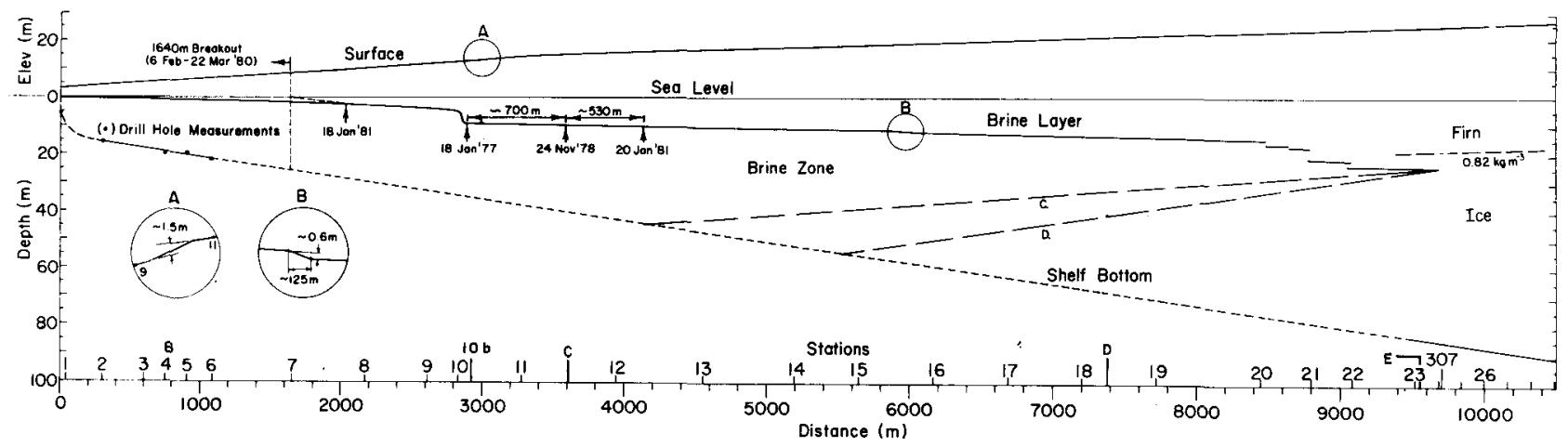

Fig.2. Cross-section of the McMurdo Ice Shelf along the radio echo profile line. Stuart and Bull (1963) first showed the ice shelf to be wedge-shaped. The height of the ice front varies in time and space and is a function of ice-shelf movement rates, break-out dates and magnitude, and the rate of bottom melting.

the next 50 to 70 a and that the ice-shelf crosssection depicted in Figure 2 will remain unchanged. In so doing, it is possible to approximate the area of the ice shelf composed of brine-soaked firn and saline ice. Thus, at a forward movement rate of $80 \mathrm{~m} \mathrm{a}^{-1}$ and a bottom ablation rate of $0.9 \mathrm{~m} \mathrm{a}^{-1}$, we can expect that, when the saline ice near station 307 reaches the ice-shelf bottom, it will be some $5520 \mathrm{~m}$ ahead of its present position and will have moved downward along path $C$ (Fig.2). Similarly, if the bottom ablation rate was $1.2 \mathrm{~m} \mathrm{a}^{-1}$, the brine ice would move forward some $4160 \mathrm{~m}$ along path $D$. Path $D$ intersects the firn/ice transition horizon about $10700 \mathrm{~m}$ inland on the cross-section. If path $\mathrm{C}$ was similarly extended it would intersect the firn/ice transition about $15 \mathrm{~km}$ inland. From earlier considerations this distance appears excessive and suggests that the ice-shelf bottom is melting at a rate nearer to $1.2 \mathrm{~m} \mathrm{a}^{-1}$ than $0.9 \mathrm{~m} \mathrm{a}^{-1}$ in the area of the cross-section. This is in keeping with measurements by Paige (1969), who determined, from ice-movement records and drili-hole measurements, an ice-shelf thinning rate of $1.06 \mathrm{~m} \mathrm{a}^{-1}$ and a snow accumulation rate of $0.27 \mathrm{~m} \mathrm{a}^{-1}$ or a total bottom melting rate of $1.33 \mathrm{~m} \mathrm{a}^{-1}$ for an area about $0.5 \mathrm{~km}$ south of the southern end of our profile line. This ablation rate was confirmed by Hoffman (1974).

The above analysis does not consider vertical brine migration, which will occur first by diffusion of brine along crystal boundaries and later by intergranular vein flow as the saline ice moves downward into an increasingly warmer environinent. A tacit assumption is also implied that the current brine terminus, being in "impermeable ice", is no longer moving inland. This is not the case. Between $18 \mathrm{Janu-}$ ary 1977 and 24 November 1978, the deepest brine

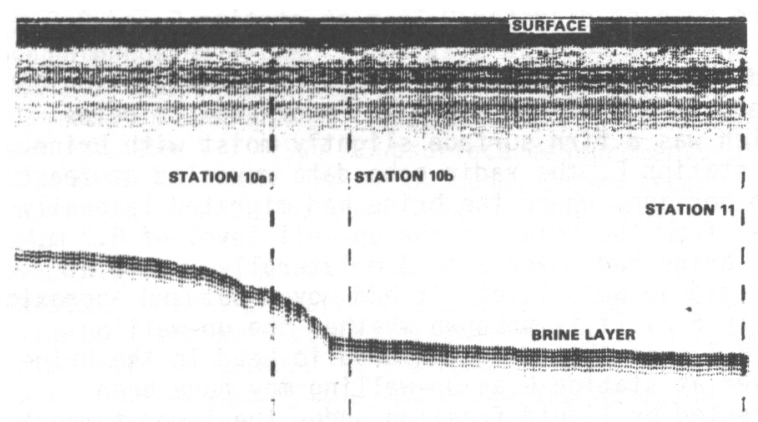

Fig.3. Graphic record of radio echo data showing the brine step of $4.4 \mathrm{~m}$.

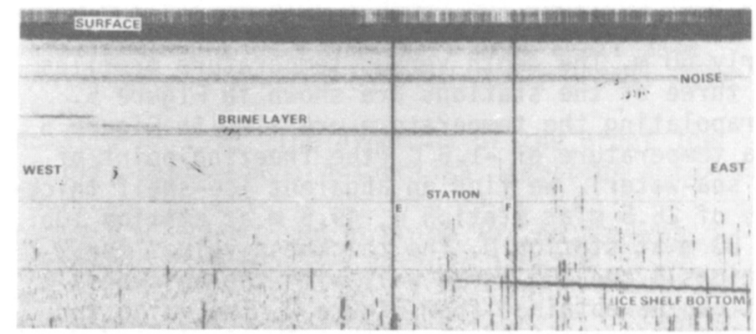

Fig.4. Graphic record of radio echo data showing several brine layers at the inland boundary of brine penetration. The fact that the ice-shelf bottom could be observed under the lowest brine layer indicates that the layer is "thin" and/or low loss with respect to electromagnetic energy transmission as the radio echo would not have been observed otherwise. Time between horizontal scan 1 ines is about 325 ns.

layer moved $27.5 \mathrm{~m}$ closer to station 307 , a rate of $0.041 \mathrm{~m} \mathrm{~d}^{-1}$. From 24 November 1978 to 20 January 1981 , the brine layer moved from $12.5 \mathrm{~m}$ before to $18 \mathrm{~m}$ beyond station 307 , an average of $0.039 \mathrm{~m} \mathrm{~d}^{-1}$. Core data from this site revealed that the brine was migrating into ice with density of $0.85 \mathrm{Mg} \mathrm{m}^{-3}$ and temperature of about $-16^{\circ} \mathrm{C}$. The calculated brine salinity and viscosity at this temperature are $230 \%$ and $5.3 \times 10^{-3} \mathrm{~Pa} \mathrm{~s}$.

The brine velocity is at least three orders of magnitude higher than simple diffusion theory through the ice lattice would predict (Hoekstra and others 1965, Seidensticker 1966). Also, calculation of fluid migration based upon Darcy's law of flow through a permeable material indicates a need for a material having a permeability significantly higher than that in the $0.85 \mathrm{Mg} \mathrm{m}^{-3}$ density ice through which the brine is migrating. "Ice with a density of $0.85 \mathrm{Mg} \mathrm{m}^{-3}$ could be permeable to brine movement because the veins at triple grain junctions would allow liquid movement under a potential gradient. However, at a temperature of $-16^{\circ} \mathrm{C}$, the veins would have to be enlarged by the moving brine in order for the permeability to reach that of temperate glacier ice (Nye and Frank 1973). Even then, the permeability due to the veins alone would be too low to account for the observed rate of movement. Accordingly, some other mechanism must account for the brine's mobility" (S Colbeck personal communication).

The calculated depth of the brine layer, as determined from the radio echo data, was verified by drill-hole measurements made in December 1978. For 
example, from the 1977 radio echo data, we calculated the depth to the brine layer at station E, $9560 \mathrm{~m}$ in from the ice front, to be $49 \mathrm{~m}$. Coring in December 1978 revealed a depth of $50.4 \mathrm{~m}$. During the preceding two winters, about $0.9 \mathrm{~m}$ of new snow accumulated. Adding this to the depth of $49 \mathrm{~m}$ gives a difference between the calculated and measured depths of $0.5 \mathrm{~m}$ or 1\%. In 1974 to 1977 , cores were obtained from several drill holes to a maximum depth of about $22.5 \mathrm{~m}$ and from four holes extending to the bottom of the ice shelf from which ice-shelf thicknesses were determined. In 1978, six holes were cored and one pit was dug along the survey line. Five of the core holes, stations $B, C, D, E$, and $F$ were located $770,3590,7370,9560$, and $9700 \mathrm{~m}$, respectively, in from the ice front. The first four holes met the brine layer at depths of $8.85,9.4,33.9$, and $50.4 \mathrm{~m}$, respectively. The pit, station $A$, located $\approx 5 \mathrm{~m}$ from the ice-shelf front, was excavated $2.5 \mathrm{~m}$ to sea-level and a hole was cored $6 \mathrm{~m}$ to the ice-shelf bottom. The core consisted of brine-infiltrated firn which was now saline ice. The last core had a sea-ice skeleton growth layer of 10 to $20 \mathrm{~mm}$ thickness on the bottom, indicating minor sea-water freezing due to winter cooling. The deepest hole at station $F$. located $37 \mathrm{~m}$ beyond station 307 , reached a depth of nearly $60 \mathrm{~m}$. The depth versus temperature profiles for three of the stations are shown in Figure 5. Extrapolating the temperature profiles in Figure 5 to a temperature of $-1.8^{\circ} \mathrm{C}$ (the freezing point of the sea-waterl, we find an apparent ice-shelf thickness of $25.5 \mathrm{~m}$ at station $B, 49.5 \mathrm{~m}$ at station $10 \mathrm{~b}$, and $80 \mathrm{~m}$ at station $\mathrm{D}$. The thickness values for stations $B$ and $10 \mathrm{~b}$ agree well with the thickness that can be obtained from Figure 2. The value for station $D$ is about $9 \mathrm{~m}$ less than the indicated depth in Figure 2. This suggests that the temperature gradient becomes steeper with depth at this location.

Least squares fit curves passing through the depth versus density core data obtained at stations $B, C, D, E$, and $F$ are shown in Figure 6 . Each curve represents the firn depth-density trend down to the top of the brine layer except at station $F$, where no brine was encountered. This figure, along with the temperature profiles in Figure 5, reveals that, as

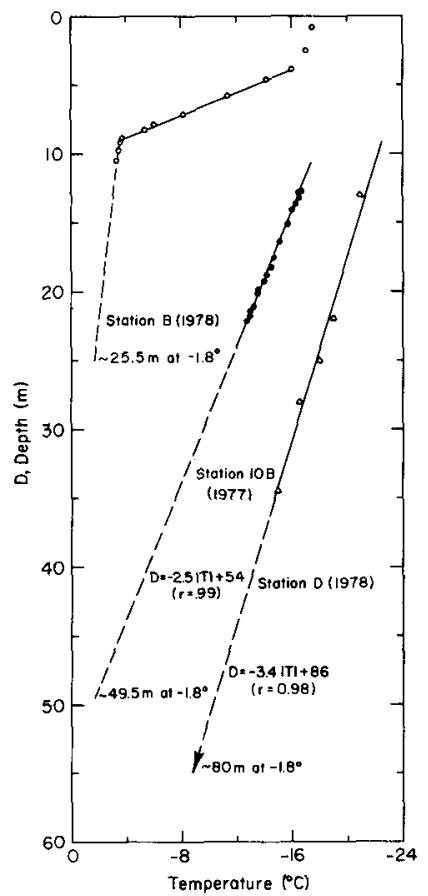

Fig.5. Depth-temperature profiles for stations $B$, $10 \mathrm{~b}$, and $\mathrm{D}$.

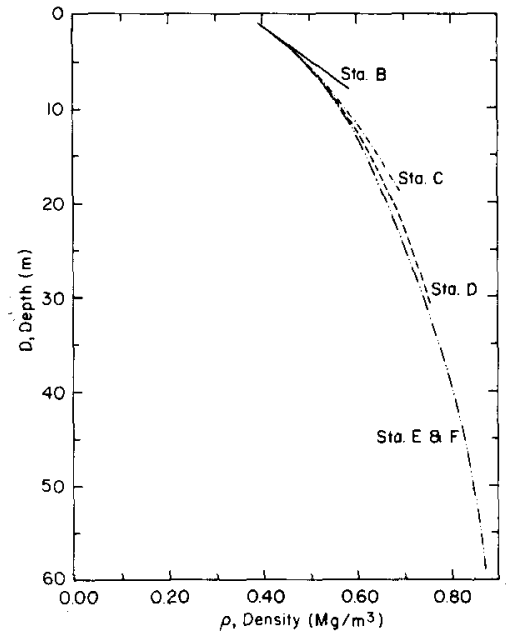

Fig.6. Depth-density curves for the firn at five stations along the ice-shelf profile line.

one moves inland on the ice shelf, the thermal and density regime of the firn changes. In short, at a depth of $10 \mathrm{~m}$ at station $B$, the snow is much warmer and denser than at stations further inland. This is due to factors related to heat transfer. Where the ice shelf is thin, more heat escapes to the atmosphere from the sea-water and larger seasonal temperature variations occur in the firn. These effects accelerate the densification process.

From the data listed in Table I we can calculate the effective bulk density of the ice shelf $\left(\rho_{a}\right)$ at station 24 from

$$
\rho_{a}=\left(1-\frac{F}{D_{T}}\right) \rho_{w},
$$

where $F$ is freeboard, $\rho_{W}$ is density of sea-water $\left(\sim 1.0275 \mathrm{Mg} \mathrm{m}^{-3}\right)$, and $\mathrm{D}_{\mathrm{T}}$ is total ice-shelf thickness. Given that the surface elevation is $25 \mathrm{~m}$ and the keel depth $K$ is $88 \mathrm{~m}$ then $D_{T}=113 \mathrm{~m}$ and, from Equation 2, $\rho_{a}$ is 0.80 .

From the values in Table $I$, the $K$ to $F$ ratio is 3.53:1 and the ice-shelf thickness to freeboard ratio is $4.5: 1$. The latter value is higher than the $4.15: 1$ ratio that would be derived from Gow's (1963) relationship based on density data from Little America $v$. The higher value for station 24 is believed to be due to brine loading and higher firn densities deflecting the ice shelf downward. A deflection due to brine loading was evident in our 1977 elevation survey, which showed a marked change in slope near station 10 (see insert A, Fig.2). This change occurred over such a short distance that it was first detected by eye and later verified by the elevation survey.

Another interesting finding from the January 1981 resurvey was that brine had risen $8.7 \mathrm{~m}$ inside the bore hole of diameter $0.15 \mathrm{~m}$ at station $E$ and $0.5 \mathrm{~m}$ in the bore hole at station $D$. Lead-line sounding indicated a hard bottom at station $E$. At station $D$, the hole bottom had $0.7 \mathrm{~m}$ of "hoar-frost", below which was a firn surface slightly moist with brine. At station $E$, the radio echo data revealed at least two horizons where the brine had migrated laterally away from the hole. At the up-well level of $8.7 \mathrm{~m}$, the brine had moved 2 to $3 \mathrm{~m}$ laterally, while at the mid-up-well level, it had moved outward approximately $5 \mathrm{~m}$. It is unknown whether the up-welling of $8.7 \mathrm{~m}$ is the maximum hydraulic head in the brine layer at station $E$ as up-welling may have been arrested by liquid freezing under the lower temperatures at the higher elevation.

Chemical analysis of brine-infiltrated cores from 
drill holes along the profile shows that freezefractionation of the sea-water, as it penetrates the ice shelf, preferentially precipitates virtually al1 sodium sulfate before the inland boundary of brine penetration is reached. For example, near the nose of the brine wave of height $4.4 \mathrm{~m}$, the sulfate to sodium ratio is essentially the same as for sea-water, or slightly higher where sodium sulfate has accumulated locally. However, this ratio decreases four-fold immediately in front of the brine wave in samples from an earlier infiltrated zone across which the new brine wave is migrating. Near the terminal boundary of brine infiltration, the sulfate to sodium ratio is reduced to less than one-tenth the sea-water value, and concomitant removal of water by freezing within the pore spaces of the firn grains has produced brines approximately seven times more concentrated than the original sea-water.

\section{ACKNOWLEDGEMENTS}

The assistance of Thomas Fenwick and Rexford $M$ Morey during various field surveys is acknowledged. John D Palmer, of the New Zeal and Department of Lands and Survey, took our triangulation station data and arranged for its computer analysis and plotting on the McMurdo area map grid. The personal consultation provided by Dr Samuel Colbeck on aspects of water migration in ice is most appreciated.

Funding for this study was provided by the US National Science Foundation, Division of Polar Programs.

\section{REFERENCES}

Clough J W 1973 Radio echo sounding: brine percolation layer. Journal of Glaciology 12(64): 141 143

Clough J W, Bentley C R 1967 Electromagnetic sounding of glacial and shelf ice. Antaretic Journal of the United States 2(4): 119-120

Dubrovin L I 1962 o rassolakh v shel'fovykh lednikakh [Brine in ice shelves]. Informatsionnyy Byulzeten' Sovetskoy Antarkticheskoy Ekspeditsii 35: $35-38$

Gow A J 1968 Deep core studies of the accumulation and densification of snow at Byrd station and Little America V, Antarctica. CRREL Research Report 197

Heine A J 1963 Ice breakout around the southern end of Ross Island, Antarctica. New Zeazand Journal of Geology and Geophysies E(3): 395-401

Heine A J 1967 The HcMurdo Ice Shelf: Antarctica; a preliminary report. New Zealand Joumat of Geology and Geophysics 10(2): 474-478

Heine A J 1968 Brine in the McMurdo Ice Shelf, Antarctica. New Zealand Journal of Geology and Geophysics 11(4): 829-839

Hoekstra $P$, Osterkamp T E, Weeks W F 1965 Migration of liquid inclusions in single ice crystals. joumal of Geophysical Research 70(20): 5035-5041

Hoffman C R 1974 Engineering manual for MeMurdo station. Revised 1979. Port Hueneme, CA, Civil Engineer ing Laboratory

Kovacs A, Gow A J 1975 Brine infiltration in the McMurdo Ice Shelf, McMurdo Sound, Antarctica. Journal of Geophysical Research 80(15): 1957-1961

Kovacs A, Gow A J 1977 Subsurface measurements of the Ross Ice Shelf, McMurdo Sound, Antarctica. Antaretic Journal of the United States 12(4): 146 148

Kovacs A, Morey R M 1979 Remote detection of massive ice in permafrost along the Alyeska pipeline and the pump station feeder gas pipeline. In Pipelines in adverse environments; a state of the art. Proceedings of the ASCE Pipeline Division Specialty Conference... 1979... New Orleans, LA. New York, American Society of Civil Engineers: 268-279
Nye J F, Frank F C 1973 Hydrology of the intergranular veins in a temperate glacier. International Association of Scientific Hydrology Publication 95 (Symposium of Cambridge 1969 - Hydrology of GLaciers): 157-161

Paige R A 1969 Bottom melting of the McMurdo Ice Shelf, Antarctica. Journal of Glaciology 8(52): $170-171$

Paige R A Unpublished. Breakout of the McMurdo Ice Shelf. US Naval Civil Engineering Laboratory. Internal Report 7

Risk G F, Hochstein M P 1967 Subsurface measurements on the McMurdo Ice Shelf, Antarctica. New Zealand Journal of Geology and Geophysics 10(2): 484-497

Seidensticker R G 1966 Comment on paper by P. Hoekstra, T.E. Osterkamp, and W.F. Weeks, "The migration of liquid inclusions in single ice crystals". Journal of Geophysical Research 71(8): 2180-2181

Smith B ME, Evans S 1972 Radio echo sounding: absorption and scattering by water inclusions and ice lenses. Joumal of Glaciology 11(61): $133-146$

Stuart A W, Bu11 C B B 1963 Glaciological observations on the Ross Ice Shelf near Scott Base, Antarctica. Joumal of Glaciology 3(34): 399414

Thomas R H 1973 The dynamics of the Brunt Ice Shelf, Coats Land, Antarctica. British Antarctic Survey. Scientific Reports 79

Thomas R H 1975 Liquid brine in ice shelves. Joumal of Glaciology 14(70): 125-136 